\title{
Performing Difference Differently: New Ways of Doing, Old Ways of Seeing
}

In our daily lives, we perform difference differently. 'We' here refers to a collective of cosmopolitan artists, members of my company: JK Productions: He Korero Ngā Tahi. JK Productions was established in 2017 as a platform for developing diverse theatre and other artistic work in Auckland, New Zealand. Our first major production was America Rex by Tom Minter, which I directed for a developmental presentation at The Auckland Performing Arts Centre (TAPAC) in August 2018. Our company was extraordinarily diverse, especially by New Zealand standards, a mix of tangata whenua and tauiwi, including some who were Indigenous, albeit in other lands (the Caribbean, Zimbabwe, Samoa, and so on). For most of us in this work, especially as members of intersecting diasporas, the colonial past remains proximate. Yet, what we make as theatre artists is not always, or even often, what an audience sees so clearly as we intend.

In our deeply collaborative performance process, twentytwo different artists were invited to be co-creators in my vision to create a transcendental theatrical experience. As a result, a range of different notions of identity, community, spirituality and aesthetics were deliberately encoded in the production that sought to displace, translocate and transcend the conventional trappings of theatre-making. There is a displacement between old ways of knowing, new ways of doing and old ways of seeing that is especially true in such cosmopolitan performances. In my production of America Rex, I saw the spectators' own experiences come into play in their reception and perception of race, ethnicity and culture onstage. For this audience, the gap between what they expected in watching actors of colour perform in ways that invoked diverse traditions was acutely destabilised because 
the play text itself is non-linear and poetic, with meanings that, as a result, were intentionally fluid.

With six black creatives (Caribbean, Zimbabwean and African-American) involved in a project that had very close affiliations to Te Ao Māori (both the lead actor and the show's designer were tangata whenua) the optics through which this production was made included a black consciousness, albeit one of the diaspora, and an Indigenous kaupapa that located the world and the work within the distinctive context of the cosmos and its heavenly bodies. Using Nigerian performance scholar and dramaturge Esiaba Irobi's seminal 2009 text on African performance aesthetics, The Theory of Ase, I would like to explore the opportunities that America Rex offered to reflect a conscious and subconscious working through of what Irobi refers to as ase, the

[. . .] spiritual, albeit, subversive episteme which acknowledges that art, including the theatre, is intrinsically revolutionary and has the power, through the phenomenological agency of its actants, to not only change reality but also transform the given existential circumstances of the playwrights, audience and even absent communities whose histories are evoked through the play. (18)

As an aesthetic performance theory, ase is distinctive to Indigenous Africans and the diaspora and a useful lens through which to regard the different mythopoetic aesthetic features of America Rex. Written by African-American playwright Tom Minter in 2003, America Rex is what Irobi would have referred to as a 'cultural text', one that offers us 'hybridised and syncretised aesthetic infrastructures that interrogate the theologies of supremacy often associated with whiteness and other manifestations of western cultural and intellectual hegemony' ('What they came with' 896). As such, America Rex is not just the name of a political drama, but the name of a place, a world that defies the current socioeconomic realities of the black and brown body, and instead, deliberately trades in the currency of what has survived and persisted across the diaspora, a currency of resistance that affirms our gods, our rituals, our ontologies and the functionality, outside the conventions of European theatre, of African-derived forms.

This was my dramaturgy, a thought-consciousness that was embedded across all facets of the rehearsal process and 
woven into the production. The reception of America Rex in Aotearoa New Zealand highlighted the challenge of producing a work that breaks with conventional understandings of the world both within and outside the theatre. For many audience members who have no or little affiliation to ritual, ceremony or initiation, the reception of America Rex was complicated by the ability to read, or more precisely, to be literate in the nonverbal and iconographic discourse - an exchange Irobi would say is shaped through ase, and which, for me, in this production took a very distinctive form: aligning the human body, voice, movement, image, costume and story outside the limits of race, culture and ethnicity, very firmly, post the colonial, post the cosmopolitan, and into the cosmos. This form of somatogenic literacy is constructed, embodied and performed by the markings of the black and brown body.

This essay offers a close reading of three key aesthetic elements - the use of images, body and sound - by looking directly at the production's African/Afro-Caribbean and Indigenous leads and the different responses of the audience to what they (thought they) saw. Reflecting upon a gathering of responses, almost three months after the close of the threeday development season, I found that there is an abyss between the presentation and the reception of experimental theatre work such as America Rex. Spectators bring with them old ways of knowing that limit their ability to see new work with fresh eyes. A singular experience in the theatre in itself is not enough to broaden the ways in which the world sees difference.

America Rex's utopian vision of a cosmic unity within my cosmopolitan company began with a dystopian premise, the last remnants of civilisation post-the-apocalypse. What the audience, for the most part, seemed to see and/or read - in their post-production feedback to me - when looking at my company of diverse racial, ethnic and cultural identifications became a narrative translated from their own defaults, their own conventional ideas of what our identities were. Regardless of their own diverse socio-cultural identifications, spectators reproduced the status quo of the dominant culture, explaining to themselves the relationships between characters, and between the characters and the stage environment, on that basis. Ironically, the play's poetics of displacement appears to have failed to provoke a conscious realisation that 'Indigenous African forms ... [are] transformed, syncretised or creolised in the African diaspora' (Irobi 'What they came with' 896). Instead 
of coming to see the tension between discrete Indigenous practices and the European, audiences, especially those unfamiliar with these forms, reflexively reverted to their preconceived ideas of culture and theatre, thus re-privileging Euro-centric models, identities, signs and verbiage.

Written in 2003, the text of America Rex had remained in the darkness of a sticky drawer until 2016, when chance and opportunity allowed both Minter and me to be in the same apartment on Manhattan's Upper West Side talking about the cosmos and the challenges of moving past the post-colonial into the cosmopolitan. Minter offered his work to me to read. It struck me as eerily prescient of our own world, one where 'a true leader makes the best choices - out of none' (America Rex 10). These are the words spoken by America Rex's protagonist, General Fisk (played by Graham Vincent, a Jamaican via the United Kingdom). Fisk is a tragic hero, striving to right a world that is on the verge of a second apocalypse. Sabotaged by power-hungry dictators, this is a collapsing existential place and time, where refugees are willing to 'die, in a plunge to grass - fake or not - than into another, desolate second of life' (America Rex 31).

In the volatile environment of the play, the threshold of reality crosses into the space of the dream-world where the imaginative and experiential become possible. A prophet, Yves, visits General Fisk, who is feeling the weight of a changing world on his shoulders. As played by James Maeva (Ngāpuhi, Cook Islander), Yves becomes a tohunga who rebukes, warns, intervenes and ultimately, offers compassion to the people who populate a world that is falling apart - with a very unlikely possibility that things may fall back together. Caught in the middle of this turmoil is Louise, the wife of Fisk. Played by Sandra Zvenyika, a Shona woman from Zimbabwe, the character of Louise is a woman desperate for power but equally, hungry for enlightenment. Orbiting these three key figures are other bodies: the Speaker, the Lieutenant, the Generals, the Guards and the Cosmic Mother - all on their own unique paths and whose intersections, collisions, attractions and repulsions populate the world of the play. America Rex is a call to re-imagine a global society, to invent alternative ways of knowing and doing for when the world begins keening upon its own axis.

With this intention, my production looked through and beyond the postcolonial to the cosmopolitan, in the first instance, by bringing together actors and artists of diverse 
backgrounds: Māori, Samoan, Greek, Caribbean, Zimbabwean, Indian, Sri Lankan, Singaporean, Chinese, Colombian, Lebanese, African American, and White English and American. This community was woven with the intention to embrace colour conscious casting, a choice that lent agency and context to a play that, in the words of the playwright, "had nothing to do with colour or race, and therefore, had precisely, everything to do with colour and race' (Minter). As a result, the dramatic action - resting on a thinly veiled doomsday premise - starts from the sure knowledge that when such a day comes, the world will reflect the people in it and those who contributed to its making.

The creatives included Jimmy James Kouratoras, a visual artist of Māori (Ngāti Tiipa, Tainui) and Cretan descent. Kouratoras is the co-founder of JK Productions and served as designer for the production. He has been working as painter for almost 25 years including, eighteen as a film scenic. His pop-colour, abstract, large-scale paintings allow his two different cosmologies to meet in works that reflect narratives of whakapapa. His artwork for the production was deeply rooted in Te Ao Māori: a distinctive and powerful set of eighteen images that through huge projections (approximately $6 \mathrm{mx} 3 \mathrm{~m}$ ) illuminated the world of America Rex. These included: a desolate landscape replete with the Great Border Barrier; the world of the seer, Yves, which was set amongst the cosmos; the very practical interiors of the Senate; the General's gymnasium; the private chambers of Fisk; tumbling refugees falling over the wall; and the forest that Louise, the General's wife, invokes when her world clashes with that of Yves.

Kouratoras created 'Louise's Forest' (Image 1) to showcase both a connection for Zvenyika, as an Indigenous woman, to ancestors and place, but also to highlight the unique experiences of different Indigenous worlds. The 'Forest' is based on the Uruweras, one of the largest regional forests in New Zealand, which is found in the centre of the North Island. The sculptural pou that rise out of the forest in this image are familiar figures in Kouratoras' work and can be seen in a number of his other paintings. During the rehearsal process, he added colour, texture and light to his artwork, working with me, as the director, to create a forest fitting of a Queen. The artwork was lit by moving lights to create a waterfall effect and the scene was immersed in the sounds of an imminent thunderstorm as Louise spoke the Shona words mabanan'ana, mhepo, muura invoking thunder, wind and water respectively. 
Drawing upon both a Shona and a Māori epistemology gave the performance its mythic and epic structure and oriented its place in the cosmos.

For some audience members, the efficacy of such ritual transformation was obvious. However, the majority, according to the responses I received, failed to see what Maximilien Laroche, a Canadian-Haitian scholar, refers to as the working of 'myth in an oral culture', whereby through juxtaposition of image, language and body, 'the sacred and the historic expresses a world order [. . .] that ties together the everyday, the ephemeral, to the atemporal, the metaphysical' (Laroche 45). Seeing an African woman, hearing African words, the audience did not see the iconographic Māori imagery used by the artist as Māori, and the scene as a meeting between two distinctive worlds. Instead, they commented on how 'African' Kouratoras' artwork had become in this production, citing this image specifically as an example.

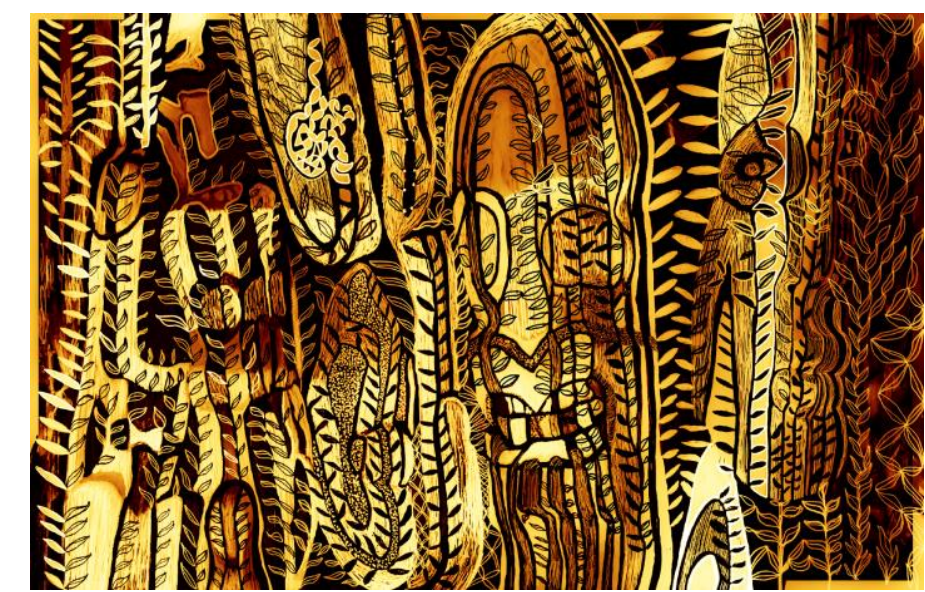

Image 1: 'Louise's Forest', Artwork by Jimmy James Kouratoras

That some spectators, including art critics, including those who know Kouratoras and his work, tended to overlook the obvious connections to his oeuvre was strange. In seeing a black actor, speaking her language, did they transplant the setting of the play from the place of cosmic apocalypse to their generic idea of 'Africa'? How could they not imagine that at the 
end of the world, we - all of us, with our own distinctive backgrounds - would be in it together, not the same, but in the mix and that that mix would be diversely coloured? Somehow the juxtaposition of a Zimbabwean woman's body speaking in her mother tongue against the backdrop of a vibrant ngahere resulted in the identification of the artwork with a continent - a cumulative interpretation that did a disservice to both the painter and the performer in conflating their very different Indigenous backgrounds.

Such mis-readings were not limited simply to the images. Although both leads in this production were black, never at any point was there an assumption within the company that their blackness was synonymous with each other or indeed, with Minter, the African-American playwright. Their identities were at once specific to their individual backgrounds and universal, particularly within the cosmopolitan world of the play and part of the cosmos to which we all belong.

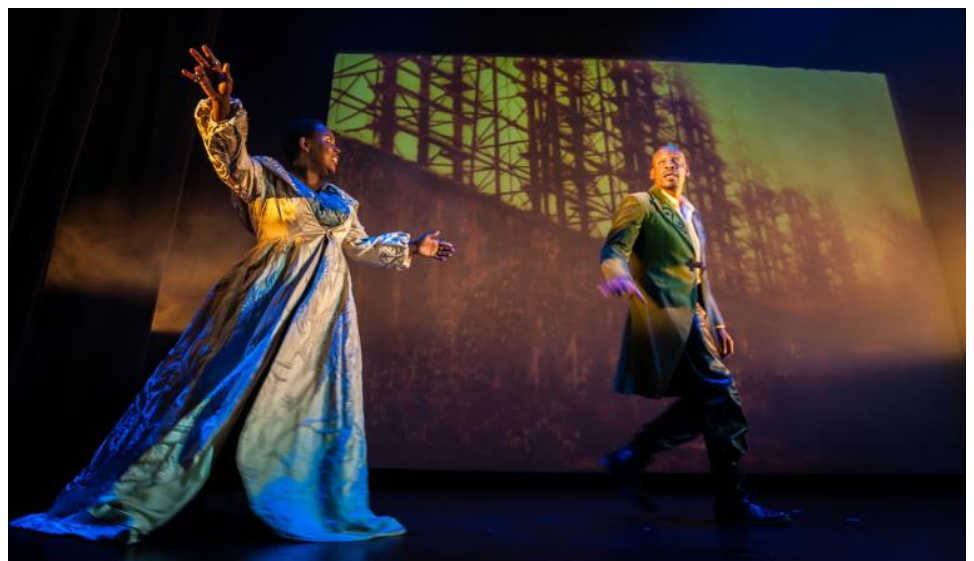

Image 2: Louise and Fisk (Sandra Zvenyika and Graham Vincent) Artwork, 'Great Border Barrier', by Jimmy James Kouratoras

In fact, the racial mix was intentionally counter to what might have been expected in a more conventionally 'colourblind' or 'non-traditional' production. For the most part, the response to this colour-conscious casting, whereby the leads both maintained their discrete cultural identities and displayed agency in their respective roles, created positive 
approbation, especially from the African and Afro-Caribbean communities, whose chief delight was in the affirmation of seeing black creatives in lead roles. Nevertheless, the seemingly endless swarm of questions that seemed benign on the surface, were troubling: 'Did you cast your leads because they were black?' 'Why didn't you have a black and white couple?' 'What's the point of them being black?' 'Couldn't they have been played by anybody since it's not a play about race?'

In reflecting upon these comments, I return to Irobi, who explains such transactions and exchanges in context of the brown body and its performance on stage. He says:

[. . .] in the sensibility or imaginary of most African and African diasporic cultures of orature, the human body is a site of discourse, the slate on which are written the most precious aspects of the narratives of life through a complex network of sonic, proxemic, tactile, iconographic, olfactory, kinaesthetic literacies and other forms of subversive intelligence. (Irobi, 'The Theory of Ase', 16)

Lacking comprehension of such diverse literacies, the audience's responses reflect a collective grappling with the problem of making meaning in the theatre. Audiences use what they already know to make meaning from what they see. In these exchanges, therefore, the question is how the old ways of seeing, while they are necessarily key to dramaturgical success, might also enable us, as theatre-makers to transition into a different space. If the performance text is always already linked onstage to the performer's visible marking - how can we make the audience see what they see as a contradiction, as a problem, as a representation deliberately constructed by our multiple selves as members of diasporas descended from the legacies of colonialism and slavery?

The audience's confusion in locating Louise's Forest in a place somewhere between the Māori and the African was as much about sound - language, voice and movement - as about the visual and the body, as evidenced in the scene where Yves performed a haka for Louise. Te Reo Māori is a language that has a rich and formidable past and has been undergoing a resurgence since the 1970s, when a number of efforts were directed to ensuring that the first language of this land would continue to be actively used for generations to come. It is also a taonga, that intertwines both tikanga and whakapapa into 
Te Ao Māori. In Minter's writing, Yves is a prophet, an Indigenous character, albeit one not vested with a particular culture, the playwright wanting to leave that choice with the director and the actor. It was intentional and fitting, therefore, that for the first outing of this work on a public stage in Aotearoa, Maeva took this role. Wearing a pareo, a formal suitjacket and a taonga made of mother-of-pearl, and wielding a patu, he was the epitome of old ways of performing a Māori self made present in a young body. Maeva, standing in contrast to Vincent (Image 3), created a very specific visual: an Indigenous man and a black man, caught in a moment among the stars. It was Maeva's use of language, and a carefully chosen haka that served as a foundation for this production.

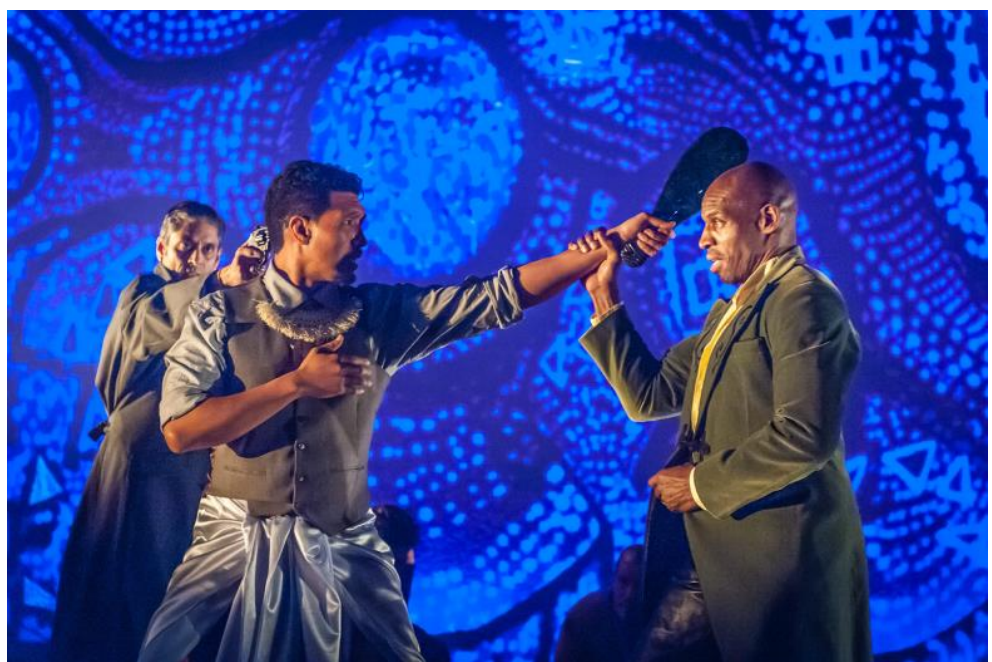

Image 3: Left-to-right: Mel Odedra as the Lieutenant, James Maeva as Yves and

Graham Vincent as General Fisk

The haka, in its sounds and movements, transcends the physical to the realm of the spiritual. Maeva decided to perform 'Tika Tonu' because, from his perspective, it best supported America Rex's underlying kaupapa: we must return to old ways of doing in order to uncover in new ways of knowing. Irobi would, perhaps, recognise in this particular 
haka a 'transcendent experience' whose texts are 'inscribed incubated, performed and translocated by the human body' (Irobi, 'The Theory of Ase', 17). In performance, Maeva's haka forged a connection between the bodies of a Māori man, a Jamaican man, and a Zimbabwean woman.

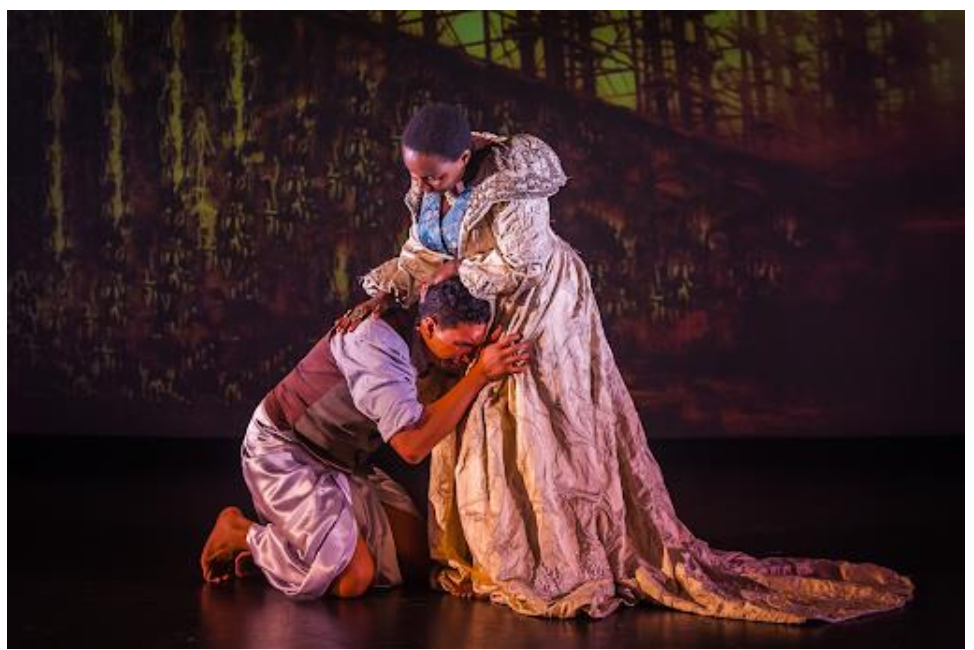

Image 4: James Maeva as Yves and Sandra Zvenyika as Louise

The interaction between Maeva and Zvenyika's characters, Yves and Louise (Image 4), once again appears to have disrupted the audience's ways of seeing. She was not merely a black Lady Macbeth dashing brains out nor was she a black Maid Marian, a valiant sidekick for her hero. She was simply Louise, a powerful and authoritative black woman, disappointed with her life and the choices she has made and mesmerised by Yves and all the potential he symbolises. Their performance together on stage, in raising not just a few quizzical eyebrows, was powerful because it seemed to shift the stability of a conventional racial relationship. While Louise spoke a mix of Shona and English, Yves moved fluently between Te Reo Māori and English, and his haka was entirely in Te Reo. 
In the same way that the audience had trouble accepting the juxtapositioning of the Māori artwork with the African body, so too they seem to have reverted to a default view of the performance of the haka. It seems that the haka has no place in the cosmos. People coming out of the theatre said things like: 'I guess you had to include a haka because you wanted a bit of Māori in there'; or 'It's strange to hear an African language on stage, especially when they're talking to a Māori'. It is possible that for most New Zealanders, the performance of encounter - kanohi ki te kanohi - is first and foremost an exchange between Māori and Pākehā, that is, between the (formerly) colonised and the (former) coloniser, between (in conventional theoretical terms) Other and Self. This trope leaves little space in the social imagination, it seems, for engagement between the Other/Self that is Māori and the other Other/Self that is anyone else of colour.

In this, Maeva's performance of the haka for Louise might be seen as a manifestation of Irobi's 'coherence deformation'. The coherence he refers to is the 'familiar conventions of European theatre that the playwright have appropriated'while the deformation occurs

[. . .] at the junction of rupture and suture where they rearrange the significations in order to weave in new histories, ideas, concepts, dynamics, epistemologies of acting, utterances that are nonEuropean which take not only the audience but also the speaking or acting subject through a decisive, transformative threshold. (Irobi, 'The Theory of Ase', 23).

This idea of deformation worked its way through America Rex in the interactions between Yves and Fisk as well as between Yves and Louise. Its performances of black and brown bodies on stage recognised - or at least attempted to maintain the visibility of - their distinct differences from each not just in physiology or gender, but in the ancestral ties that orient them not only in the world of the play but in the world we inhabit outside the theatre. Our production attempted the deformation of the conventional ways of seeing our black and brown bodies, not by presenting a homogenising 'we are the world' kind of vision, but rather by maintaining our differences in a shared space and time: a cosmopolitan vision of the cosmos. The inability of certain audience members to recognize how language continues to be a portal of voiced 
socio-cultural and political identifiers reveals more about our community in Aotearoa and the lack of engagement with new ways of doing, that are, for some of us, in fact, very very old ways of knowing.

Douglas $J$ Loveless, in '(Un)becoming the I: A Duoethnography of Displacement', suggests that in order to become a

[...] convincing I we have to unbecome another I. You deconstruct in order to construct another I. Every moment of displacement creates the opportunity to unbecome the I and critically investigate who we are to ourselves and to others. (119)

The world of America Rex calls for a precise unbecoming. However, when perception is directed largely by visual association and defaults into dominant paradigm of inherited systems of power and class there is little room for deeper understanding or negotiations of identity. The markings of identity and culture (or race if we were to do away with euphemisms) remain the only handles upon which a large majority will grasp. In our company, we had a community of individuals who were all strong in our histories, knowledges and cultures. Many of us see our identities through the historical lenses of slavery, colonialism and segregation. Being conscious of how our identities have been constructed can be seen in retrospect as a way of attempting to de-form the coherence of default narratives that constrain the way we perform and interact with each other on stage as in life. We chose to become a cosmopolitan company, our international paths crossing on the local stage in ways that moved us beyond customary polemics of identity crisis toward a cosmic reckoning that we invited our audience to join on their own terms, even if those terms were limited by their own social frameworks. Through our process and in performance, we created a new orbit in which to explore the intersecting pathways of old ways of doing in order to discover new ways of knowing. In America Rex we occupied the space of the ephemeral and the transcendental, between the past and the present, the present and the future. The future may be dystopian, but our place within it does not have to be so. 


\section{References}

Bodle A. \& Loveless D.J. '(Un)becoming the I: A Duoethnography of Displacement'. Interdisciplinary Reflective Practice through Duoethnography, edited by Sawyer R., Norris J. Palgrave Macmillan, New York, 2016. 103-120.

Irobi, E. The Theory of Ase: The persistence of African performance aesthetics in the North American diaspora August Wilson, Ntozake Shange \& Djanet Sears'. African Theatre 8: Diasporas (2009): 15-25. www.jstor.org/stable/10.7722/j.ctt81npw.7.

Irobi, E. 'What They Came with: Carnival and the Persistence of African Performance Aesthetics in the Diaspora'. Journal of Black Studies $37.6 \quad$ (2007), 896-913. http://www.jstor.org/stable/40034960.

Laroche, M. 'The Myth of the Zombi'. Exile and Tradition: Studies in African and Caribbean Literature, edited by Rowland Smith. London: Heinemann, 1976. 44-61.

Minter, Tom. Personal communication. 18 August 2018.

Dione Joseph is a theatre practitioner with a professional and academic background in the performing arts. Working from a community and cultural engagement position, she has directed and dramaturged a range of theatre works and has published extensively as a stage critic and arts journalist. She has travelled internationally to China, Canada, Austria, the UK and USA on various residencies, fellowships and community invitations; this has led to an expanding body of scholarship with an emphasis on Indigenous performance. She holds an MA in Community and Cultural Development from Victorian College of the Arts, University of Melbourne. 